\title{
Children's bodies in time and place; an onto- epistemological approach
}

Nina Rossholt, Oslo and Akershus University College of Applied Sciences, Norway. Nina.Rossholt@hioa.no

\section{Abstract}

Working with concepts from Foucault and Deleuze I analyze how the youngest children relate to matter and the environment around them in a preschool context. The children are always connected to space, time and place and here I analyze how space, time and place are linked to the body in an epistemological and ontological sense. I research the daily life in preschools, analyzing early childhood spaces in an environment comprising water, sand, spades, leaves, trees, clothes, buildings, other bodies, etc. These relate further to how movements are situated, not only in language, but in bodily practices. From this angle I also make my selves as a researcher visible both during my fieldwork and in the writings.

Keywords: bodies, movements, materiality, time, place, ontology, epistemology, becoming.

\section{Introduction}

In this article my methodological approaches are linked to post structural theories paying attention to body/ place relations working from the children and the researchers' bodies. I present a critique of a dualistic thinking between theory and methodology, as well as the complex relations between the data and the researcher (Davies, 2000a, 2000b; Lather, 2007; Somerville, 2008). I probe my own ways of looking in a methodological sense, following Foucault's concept of knowledge and power as I analyse movements in bodies and materiality. This discussion is further inspired by Deleuze and Guattari (1987) asking my own multiple selves how I might open my intuition and sensibility when the body is at the center of my subjective gaze in terms of what I look at and why.

Following Somerville (2008) I ask how attention to the doing, as movement, appears as data collection from an epistemological point of view, and how subjectivity in movement relates to questions of place and time in an ontological sense. Here, we may turn to Foucault's critical ontology (Foucault \& Rabinow, 1984). Foucault challenges the modern concept of ontology. For Foucault ontology is not a fixed, given reality. "What we are" is the product of history, discourses, bodies, nature and many other factors" (Hekman, 2010, p. 58). It is how we analyze how these forces come together and construct our reality that is the matter from this ontological approach. As Hekman (2010) underlines; Foucault is not only focusing on discourses, but also on the connection between the discursive and the non-discursive, the discursive and the material, an ontology-in-practice. Foucault shows that subjectivity is constituted by the material practices of schools and prisons (Casey, 1997). As schools and prisons the preschool constitutes certain discursive practices in different space. To accomplish this, I research the daily life in preschools, analyzing early childhood spaces in an environment comprising water, sand, spades, leaves, trees, clothes, buildings, other bodies, etc. These relate further to how movements are situated, not only in language, but in bodily practices. So every movement involves variations of tempo and energy and compositions of low and high tones in an ontological sense (Deleuze, 2005; Deleuze \& Hand, 1988). In this sense, my approaches focus on changing ways of thinking about methodologies and research, rather than on calling for actions. 
So working with the body as a methodological starting point I analyse what bodies do, and how bodies connect to time and place. The body in a Deleuzian sense also includes different forms of physical processes such as movements and physical positions (Hickey-Moody \& Malins, 2007). In working from the body I analyze how children constitute differently embodied subjectivities in different places and seasonal changes as I move together with the children.

My research question is as follows: If the body always exists in relation to space in time and place, in what ways does this become apparent as I perform qualitative research among the youngest children in preschool? I now extrapolate from the larger study, which involved the collection of data from a particular group of children at the age of one and two years in two preschools (barnehager) in Norway over a twelve-month period (Rossholt, 2009, 2010, 2012).

In the first section, I contextualize my study. I then discuss my fieldwork and how theories and methodologies are linked with the help of Deleuze, Guattari and Foucault's writings. The elements that are considered follow the rationale of how, in this article, the material as the sand, water, leaves, spades and clothes etc. works on/with the body. I then introduce the body, analyzing the material in time and place. The last section details my presentation and discussion of selected moments from my data.

\section{Contextualizing the study}

The preschools in my study were both situated close to Oslo, the capital of Norway, near a little forest and surrounded by a lot of trees and fields. I spent approximately six months attending each preschool, and participated three days every week. In one of the preschools, rocks were part of the outdoor landscape. In the other preschool, a small hillside at the corner of the preschool-ground made the outdoor setting an attractive place to situate the children's play in all seasons. As I wanted to incorporate bodily interactions with the environment in all four seasons, the fieldwork took a year. The children in both preschools were aged from one to nearly three years. Due to the seasonal weather variations in Norway, the children were dressed differently. In summer, the children mainly wore a t-shirt and pants, while during the winter, when there was snow on the ground, the children were very heavily dressed, and this greatly affected their body movements. The children were outdoors all year round, but in summer they used the outdoors setting more. In the morning, before eating and sleeping, they spent time outdoors playing. In the afternoon, after a nap and before the next meal was served, whether they spent time indoors or outdoors depended on the weather. In this article my data presented is from the spring and summertime.

I situate my multiple and subjective selves in different locations/spaces inside and outside the preschool, spending my time writing about how the children related to the material and the other bodies around them. My field notes were written in everyday language, originally in Norwegian, and present stories about what the physical environment of nature gives us. The field notes present different events of children's movements; mixed with observations of seasonal weather. The children and I were more or less a research team - we did research together, not in the conventional sense, but because we investigated more or less the same matter. We studied, among other things, the water, sand and leaves. The children showed me the field while we shared the same space and activities.

I want to present the children through their movements and not through their words; furthermore, I am not the expert "saying what things meant" in terms of "data" (Lather, 2007; Somerville, 2010). In this way, my body was used as my "camera," but I chose not to used video because my interest was in the actual processes of writing, as well as the bodies' effects on thought and action (RheddingJones, 1996). Yet, I was afraid to lose focus in failing to write down the stories at once, so although my focus was on the children, it was also on me. I have attempted to capture this in the writing of my 
logbook. In my research, I used a pen and a little book to visualize how my hands were occupied; still, I was not writing constantly. When my hands left the pen and the book, they were holding children's hands, touching a face, or holding a spade in the sand pit. Sitting or lying down on the floor or the ground allowed me to see things with which the children were occupied. When I was standing, some of the children asked me to sit down or become smaller in a physical sense. So my way of positioning myself bodily was influenced by the other bodies around me. I embodied the children's relations as I wrote by hand. Any writing is embodied, but writing my field notes while sitting in the middle of the sand pit or on the ground outside challenged me to visualize how the children sometimes, though not always, had the power to correct my bodily position. Some of the children wanted me to sit in certain spots, by saying: "sit here" or pointing at the spot. They took my pen and drew lines in my logbook while I was writing. We were in a way drawing together, but with different letters and signs. Letting the children make drawings or picture as a part of the fieldwork is a part of the methodological discussion whereby many aspects can be involved in child research (Somerville, 2010).

\section{Movements of/in bodies}

My focus and analytical gaze were on how the youngest children made themselves visible through different energies, tempos, and tones. This follows my ontological question concerning what a body may do (Colebrook, 2000; Deleuze, 2005; Rossholt, 2009, 2012)

Through the type of analysis mentioned above, it can be seen that movements as physical processes involving tempos and energy, in the outside environment connecting to the materials during summer in the present research may open up our senses to what is not yet known, composing a more powerful body in research and practice (Deleuze \& Guattari, 1987). What is not yet known may be the researcher's taken for granted knowledge about the children in preschool.

Entering the preschool, I could not see the particles of the body, but children moving their bodies at various speeds and tempos, sitting, moving, or lying down. In this research project, I repeatedly saw bodies moving in different directions, using feet and hands at various tempos and with low and high energy attached to different matters. Bodies are always in touch with something or someone and bodies are never without energy, tempo or tones. While I am sitting in the sandpit I write down what the children play with and how the sand works on bodies in different ways. The children sit in the sand touching cars, dolls, spades etc, and the hand always makes new directions. I encourage myself to write about daily moments that happened all the time, like everyday life, as the children play with sand as mentioned, and with the sand and the water. I will analyze the sand and the water later in the article.

Following making these observations, I have attempted to analyze how children carry out their daylong practices. How to study this relates to researcher subjectivity in the research process, but my gazes as a researcher is not neutral, and I am responsible as a researcher when it comes to collecting data. Thus, I have to further ask myself how I can produce research that is useful to children (Pillow, 2000). Writing about my position as a researcher is not about me as a person, but how I tried to create circumstances necessary for the children during my fieldwork and through my field notes. In the next sections, I introduce time and place as methodological ways of seeing and thinking materiality.

\section{Bodies/time}

Though the body is always related to space, time, and place, theoretical writing about the body generally constitutes the body in isolation from the physical spaces in which it exists (Davies, 2000b). 
In my research, as noted earlier, the physical focus is on how children relate to each other, to the adults, and to the matter or materials around them, and how children move using their hands and feet, and how they are always related to time and place.

Following Deleuze (2005) and Fox (2002), a person is defined not by essential conceptions of age, but by his/her unfolding and changing (bodily) relations. Paying more attention to the doing or the material than to the representation of age destabilizes discourses of age to make apparent a more democratic way of thinking. Here, Deleuze reminds us that concepts are not just labels that we attach to things (Colebrook, Fensham, \& Threadgold, 2002; Deleuze, 1995). Moreover, Grosz recalls to us how our concepts of time might result in new concepts of nature, culture, and subjectivity, as time is a temporal force in its becoming (Grosz, 2005). "Becoming," in a Deleuzian sense, is to think differently; for in a world of becoming, what something "is" is always open to what it not yet is (Colebrook, 2002).

My theoretical position on this becoming issue is that the material matters when a child constitutes his or her subjectivity among others during the day. This theorization arises because of the focus on time and place. I connect this to Grosz (1994), who says that working from the body is an open materiality. In making this connection, I become more and more aware of how the physical elements relate to time. Time in a concrete and a material sense may relate to the seasons of winter, spring, summer, and autumn, as the elements of nature change during the year. When children fall on the ground, they position themselves in relation to these natural elements, and situate themselves bodily. They notice and react to a leaf or a stick. Thus, the wind affects the body, and the matter of nature causes us to visualize how we are always in relation to the landscape surrounding us. It appears that working with time and place is not necessarily related to age, but more to the researcher's engagement with a body/place position. I saw the children embody the seasons in every sense-through their clothes, their weight and size, and their ways of acting in time. Before Easter, while Pål is standing outside, his body is taken by the wind. He seems surprised and his face expresses discomfort. Then later in the day Pal is lifted up by practitioners over a log in the sand pit. About a month later, Pål is running after another boy, and his clothes and hairstyle are quite similar to those of the older boys around him.

Children's physical appearance changes very quickly during their first month in preschool. Here, the concept of time in relation to the physical body and space changes in preschool from one month to another at the age of one year. I am saying and showing here that time is visualized in relation to tempo, to slow and fast tempo and movements, to slow and rapid movement, and to movement in relation to other movements. These are further linked to different bodily expressions such as for example crying, laughing, and eating, with different compositions of energies and tempo (Rossholt, 2009, 2010, 2012).

\section{Body/place}

From writing about children's bodies as moments, I became more aware of how the material of the season formed a part of the children's embodied being in the world. The children themselves introduced me to the leaves, the sand, and the water. I wanted to visualize what the children and I saw, which are maybe not seen as valuable ways of looking and knowing about the body in traditional research. In working with methodological concepts such as place in relation to moments, the bodies become visible in complex ways. Here, the subjectivity is constituted through different discursive practices related to how place as material structures create and limit. Place constitutes different bodily practices, as these have physical and material properties, as well as discourses that enable different social relations among children. 
The way in which I present my field notes might be naïve in the sense that everybody can make field notes about how bodies relate to nature or to each other. Beyond this, however, I attempt to appreciate body/place relations and the doings of the children, and at the same time to connect my own body to these observations. Therefore, next I present some moments from my fieldwork in relation to what I "saw" in the fieldwork and why. The text that follows is about body/place relations.

\begin{abstract}
It is the middle of the day. It is a warm summer day in June, and nearly all the children are outside. When I arrive at the preschool, all the children have taken their clothes off and are wearing only bathing suits or underwear. The water sprinkler has been brought out and placed on the grass between the sand pit and the swing. The hose doesn't work, so the practitioners have to fix it before the children can run into the water. One of the practitioners leaves the preschool and goes to the tap placed on the wall. The water is running out of the tap and after some minutes a big puddle of water mingles together with the sand on the ground. The youngest ones, Lars and Per, aged two, position themselves in the water pool. They are smiling as they say to me: "Have you written down that we are bathing?" I answer "Yes." Isak, aged two, is also sitting in another container of water and sand, warmed up by the sun. The water flows in and gets mixed with the sand. Kari, aged four, comes along. She says she wants Isak's spade. She is in front of Isak. Isak raises his arm, holding the spade in his right hand as he sits in the sand pit. While he is doing this, he lifts his left hand and points, showing Kari another spade lying on the ground.
\end{abstract}

While the youngest children's bodies are situated in the sandy water, most of the older children have not yet started to play with the water, as they are waiting for the water sprinkler to be fixed. Here, the sun, the water, and the sand invite the youngest children to use what is in front of them. Their focus is on the running water and how the sand makes paths in the water. While this is happening, some of the staff becomes more and more stressed as they wait for the hose to be fixed. After half an hour, the sprinkler is working. The oldest children happily run into the water again and again. The youngest children are still sitting in the sandy water, but they are now without any new fresh water, since the water is now coming from the hose. From the staff's point of view, the pedagogical goal was reached when the water sprinkler was fixed, because until this time, the children could not play as was planned. Ironically, among the youngest children, the play stopped at this point, because the water they were using was nearly gone. In this context, playing constitutes ways of being in an ontological sense, connecting children's imagination and their construction of the context (Løkken, 2000 , 2004). The moment above shows how subjectivity might be visible through children's energies, desire, and materials in time and place, as subjectivity is enacted not only through discursive processes, but also through material ones (Foucault, 1980). How the youngest children position themselves through available discourses might thus include how they "do" their body during the day (Søndergaard, 2005), not as a fixed category, but as a way of becoming.

The materials present in the moment described above are the sun, the water, the sand, the spade, and the bodies. The warm water and the sand surround the body, specifically the legs, the feet, and the bum. The smiling faces appear to indicate a positive energy among the children, as they become creative, making all the changes on the ground, mixing the sand with water and leaves. Isak could have raised his left arm halfway to hit the girl. Instead, he positioned himself as a person who was stabilizing the situation by pointing to another matter nearby. From this perspective, the doing is always like a chain of actions, like a composition of speed and slowness. We may use Deleuze to underline how "One never commences, one never has a tabula rasa, one slips in, enters in the middle; one takes up and lays down rhythms" (Deleuze, 2005, p. 59).

A further analysis of the moment above shows how the place changes as the water starts running. The hot, dry sand becomes wet and invites the youngest children to sit down. They create a new 
place for themselves; meanwhile, the many older children make a lot of bodily expressions in the form of high tones and fast movements. However, the youngest children also create new relations with the materials around them. We could say that this is what children at this age do and that there is nothing special about it, but we might also look at these movements in another way. How the youngest children use their time is quite different to how the older children use it. In relation to time, the youngest children did not wait for the pedagogical changes as directed by a practitioner. Furthermore, in relation to place, as the children were situated near the water from the water tap, they saw and touched the water, and started playing with it.

\section{New positions of knowing}

As discussed above, both Foucault and Deleuze and Guattari analyze the complex dynamics of time and place (Somerville, 2008). I take this further by presenting how the sandy water takes new directions all the time as floodwater or storms in the sea. In this sense, the water makes new possible ways of becoming. Analyzing material forces make visible how the wind, the leaves, and the sand on the ground do not move in straight lines, but work more like a spiral, as an ongoing series of moments. This has implications for how the preschool environment interacts with the children and how researchers analyze moments as event-like knowledge. Such knowledge is often a taken-forgranted kind of knowledge, viewed as how humans connect to nature. The research informing these theories involves a series of highly selective moments constructing bodies, relating to some Foucauldian effect regarding power and truth (Foucault \& Rabinow, 1984)

Moments are connected physically to places, and here place informs my epistemology; different places have their different normative rules for the staff and for the children in the preschool. The moment presented above shows how children embody the material around them. The material, the sand, and the water may be linked to the discourse of age, as the body is positioned and situated in the world. Here, I suggest that analyzing the body in relation to the material destabilizes age. Thus, through my textual practices, I try to move toward some place of both/and and either/or. The extract that follows focus on this thinking about body/place, as the body is always in place:

Occasionally the children start to make sounds/words to themselves or to these materials. At other times they start to communicate with me or the practitioner about what they have in their hands or what they are seeing and touching. It is fascinating how one boy communicates through the environment around him. He is always picking up a stone, a leaf, or a splinter from the wood surrounding the sandpit. He seems to see things that I have more or less forgotten about or am not focused on at the moment.

Reading Somerville's (1999) book Body/Landscape Journals, I see a similarity to my reflections on the children in how Somerville makes aboriginal woman visible through the landscape (Somerville, 1999). Although I do not want to suggest too much similarity between Somerville's text and my moments, I do try to analyze how bodies are constituted along with the world, or rather as "part of the world" (Barad, 2007). Often, in research, we ask why children do the things they do. Following Lather (2001), we will not ask about the meaning of the doings, but rather how the body relates to the matter presented, as in a Deleuzian sense, energy and tempo are situated in time in relation to matter. This, then, is not a discussion about "the meaning," but rather about "the pleasure" of being a body that feels the water around itself, the sand between hands, and the sun in the face. As I read Foucault, I follow his advice, as he wants us to see what frames our seeing in relation to power-knowledge, and try to challenge new positions of knowing (Foucault, 1980). Thus, power can be understood in terms of movements, and children can be empowered by visualizing data as movements. In the next section, I analyze further how one movement is intertwined with another movement, and how my analytical strategies are influenced by movements such as energy and tempo. 


\section{Slow and fast tempo and rest}

Deleuze and Guattari's approach consists not in assessing bodily cause and effect, but in counting what they call the "affects" or "relations" of a body in an ontological sense. The body is composed of an infinite number of particles, and incorporates emotional and physical attachments that may be many or few in number (Deleuze \& Guattari, 1987). I suggest that it is the relations of motion and rest, and of speed and slowness between particles, that defines a body-the individuality of a body (Deleuze, 2005 p.58). Moreover, a body may further affect other bodies, or be affected by them (Rossholt, 2009). The moment that follows presents children playing on a hillside.

The sun is shining, and the mild weather in April has taken the snow away. The children may have only trousers and sweaters on now. Their winter boots have been replaced by shoes. The outdoor area in this preschool place is surrounded by trees. The children play on the hillside. They run after each other in circles using slow and fast tempo. As a wind is blowing in the air, four or five boys run after each other. One of them starts making sounds, and after some seconds the others join in. The speed and fast tempo as the children run after each other, melt together with the joy of sounds. Væ, væ, væ sounds are coming out of the mouths of the children. [They will soon be speakers of Norwegian, so these are the sounds they make]. Then suddenly the tempo and the sound stop. Bodies are falling down on the ground. Bodies are lying on the ground. After a minute or two, it all starts again. Bodies are running after each other.

Analyzing movements in time and place allows me to re-visualize how body movements require slow and fast tempo and rest. In working from the body, we write about how movements make knowledge, and how movements are both an ontological and epistemological issue. We are made to move. We move all the time, from the time we are born. But movements are often analyzed in very early life and are, in a Foucauldian sense, inscribed in institutions related to taken-for-granted knowledge or linked to a developmental model of childhood (James \& Prout, 1997; Somerville, 2010). In the moment described, running is followed by rest. In running around, the feet are on the ground, but in falling down the whole body faces the ground. The children smell and see different materials from this bodily position. Here slow and fast speed and movement are regulated by discourses of space. The energy is not only an individual energy; the boys create it together as a "we-ness" (Nilsen 2000). Similar and dissimilar movements compose a particular rhythm together with the sound and smiling faces, like a dance. As human beings, we cannot constantly run and run; we have to rest sometimes, too. Like the wind on the sea, the body makes a movement and falls down on the ground or the earth. Unlike the wind, the body is always linked physically with one or many parts on the ground, or through matter, such as a bike, a stone or a chair (Barad, 2007). There are physical and verbal variations among children of the same age. As subjects, they use their bodies differently in relation to tempo. Thus, researching such bodies is not only a question of how one does one's fieldwork, but how the researcher analyzes what she/he sees and why (Nilsen, 2005).

To sum up, in working from the body, children constitute differently embodied subjectivities in different places and seasons. Through their bodies, they explore how they might use different places and materials in the preschool, and how they might relate to each other. The diversity in how children relate to each other and what they see makes age a complex study.

I asked at the beginning of the article how movement relates to questions of place and time in an ontological and epistemological sense as a theoretical/methodological approach. In this way, I have elaborated movements in bodies as an analytical strategy at the center of my research practice. Accordingly, I have asked how bodies entangle in time and place in a preschool setting. What I have found to add to the available knowledge about qualitative research is that analyzing movements as 
data links to how the researcher writes about very young children as a material practice in various ways.

Through the analysis of movement as data, children are shown to relate physically to each other, to the environment, and to the material around both epistemologically and ontologically. The research material creates knowledge about children under three, but not as an explicit discourse or representation of age. Analyzing movements as data in relation to time and place gives materiality a position in research, and points to new "bodylines" that may become visible. Doing research from and on the body creates a more curious awareness of how moments as event-like practices create, produce, and unsettle normalized practices of looking, doing, and thinking in educational research. Working from the body as a researcher, childhood studies can benefit from poststructural philosophical theories and methodological approaches regarding young children's embodied materiality in time and place.

\section{References}

Barad, Karen (2007). Meeting the Universe Halfway: Quantum Physics and the Entanglement of Matter and Meaning. Durham: Duke University Press.

Casey, Edward S. (1997). The fate of place: a philosophical history. Berkeley, Califonia: University of California Press.

Colebrook, Claire (2000). From radical representations to corporeal becomings: The feminist philosophy of Lloyd, Grosz. Hypatia, 15(2), 76-93.

Colebrook, Claire (2002). Gilles Deleuze. London: Routledge.

Colebrook, Claire, Fensham, Rachel \& Threadgold, Terry (2002). Understanding Deleuze. Crows Nest, N.S.W. Australia: Allen \& Unwin.

Davies, Bronwyn (2000a). A body of writing, 1990-1999. Walnut Creek, California: AltaMira Press.

Davies, Bronwyn (2000b). (In)scribing body/landscape relations. Walnut Creek, California: AltaMira Press.

Deleuze, Gilles (1995). Negotiations: 1972-1990. New York: Columbia University Press.

Deleuze, Gilles (2005). Ethology : Spinoza and us. In M. Fraser \& M. Greco (Eds.), The Body: A Reader (pp. 58-61). London: Routledge.

Deleuze, Gilles \& Guattari, Félix (1987). A thousand plateaus: capitalism and schizophrenia. Minneapolis: University of Minnesota Press.

Deleuze, Gilles \& Hand, Seâan. (1988). Foucault. Minneapolis: University of Minnesota Press.

Foucault, Michel (1980). Power/knowledge: Selected interviews and other writings 1972-1977. Brighton: Harvest Press.

Foucault, Michel \& Rabinow, Paul. (1984). The Foucault Reader. New York: Pantheon Books.

Fox, Nick J. (2002). Refracting 'health': Deleuze, Guattari and body-self. Health: An Interdisciplinary Journal for the Social Study of Health, Illness \& Medicine, 6(3), 347-363.

Grosz, Elizabeth (1994). Volatile Bodies: Toward a corporeal feminism. St. Leonards: Allen \& Unwin. 
Grosz, Elizabeth (2005). Time travels: feminism, nature, power. Durham, N.C.: Duke University Press.

Hekman, Susan J. (2010). The material of knowledge: feminist disclosures. Bloomington: Indiana University Press.

Hickey-Moody, Anna \& Malins, Peta (2007). Introduction: Gilles Deleuze and Four Movements in Social Thought. In A. Hickey-Moody \& P. Malins (Eds.), Deleuzian Encounters, Studies inContemporary Socail Issues (pp. 1-24). Hampshire: Palgrave, Macmillan.

James, Allison \& Prout, Alan (1997). Constructing and reconstructing childhood: contemporary issues in the sociological study of childhood. London: Falmer Press.

Lather, Patti (2001). Postbook: Working the Ruins of Feminist Ethnography. Signs: Journal of Women in Culture \& Society, 27(1), 199-228.

Lather, Patti (2007). Getting Lost: Feminist efforts toward a double(d) science. Albany: State University of New York Press.

Løkken, Gunvor (2000). The playful quality of the toddling "style". International Journal of Qualitative Studies in Education (QSE), 13(5), 531-542.

Løkken, Gunvor (2004). Greetings and Welcomes among Toddler Peers in a Norwegian Barnehage. International Journal of Early Childhood, 36(2), 43-65.

Nilsen, Randi Dyblie (2005). Searching for analytical concepts in the research process: Learning from children. International Journal of Social Research Methodology, 8(2), 117-135.

Pillow, Wanda (2000). Exposed methodology: the body as a deconstructive Practice. In E. St. Pierre \& W. S. Pillow (Eds.), Working the ruins: feminist poststructural theory and methods in education (199-219.). New York: Routledge.

Rhedding-Jones, Jeanette (1996). Researching early schooling: Poststructural practices and academic writing in an ethnography. British Journal of Sociology of Education, 17(1), 21-37.

Rossholt, Nina. (2009). The complexity of bodily events through an ethnographer's gaze: focusing on the youngest children in pre-school Contemporary Issue in Early Childhood, 10(1), 55-65.

Rossholt, Nina (2010). Gråtens mange ansikter; toner og tempo i barnehagen. (The many faced cry. Tone and tempo om preschool). Nordic Studies in Education, 30, 102-115.

Rossholt, Nina (2012). Food as touch/touching the food: The body in-place and out-of-place in preschool. Educational Philosophy and Theory, 44(3), 323-334. http://search.ebscohost.com/login.aspx?direct=true \&db=aph\&AN=73522583\&site=ehost -live

Somerville, Margaret (1999). Body/Landscape Journals. North Melbourne: Spinifex Press Pty. Ltd.

Somerville, Margaret (2008). 'Waiting in the chaotic place of unknowing': articulating postmodern emergence. International Journal of Qualitative Studies in Education (QSE), 21(3), 209-220.

Somerville, Margaret (2010). A Place Pedagogy for 'Global Contemporaneity'. Educational Philosophy \& Theory, 42(3), 326-344. 
Søndergaard, Dorthe Marie (2005). At forske i komplekse tilblivelser : kulturanalytiske, narrative og poststrukturalistiske tilgange til empirisk forskning (Reseach in complex becomings: cultural, narrative and poststructural analyses through empircal research)). In Gerd Christensen \& Torben B. Jensen (Eds.), Psykologiske og pædagogiske metoder. Kvalitative og kvantitative forskningsmetoder i praksis. (Psychological and pedagogical methods. Qualitiative and quantitiative reseach methods in pratice). (pp. 233-269). Roskilde: Roskilde Universitetsforlag. 